\title{
Transatlantica
}

Revue d'études américaines. American Studies Journal

2| 2017

(Hi)stories of American Women: Writings and Rewritings / Call and Answer: Dialoguing the American West in France

\section{Alice Kessler-Harris and Maurizio Vaudagna, eds., Democracy and the Welfare State. The Two Wests in the Age of Austerity}

\section{Luc Benoit à la Guillaume}

\section{OpenEdition}

\section{Journals}

Electronic version

URL: https://journals.openedition.org/transatlantica/10497

DOI: 10.4000/transatlantica.10497

ISSN: 1765-2766

Publisher

Association française d'Etudes Américaines (AFEA)

Electronic reference

Luc Benoit à la Guillaume, "Alice Kessler-Harris and Maurizio Vaudagna, eds., Democracy and the Welfare State. The Two Wests in the Age of Austerity", Transatlantica [Online], 2 | 2017, Online since 19 April 2019, connection on 02 February 2023. URL: http://journals.openedition.org/transatlantica/ 10497 ; DOI: https://doi.org/10.4000/transatlantica.10497

This text was automatically generated on 2 February 2023.

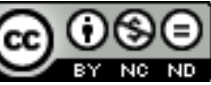

Creative Commons - Attribution-NonCommercial-NoDerivatives 4.0 International - CC BY-NC-ND 4.0

https://creativecommons.org/licenses/by-nc-nd/4.0/ 


\title{
Alice Kessler-Harris and Maurizio Vaudagna, eds., Democracy and the Welfare State. The Two Wests in the Age of Austerity
}

\author{
Luc Benoit à la Guillaume
}

\section{REFERENCES}

Alice Kessler-Harris and Maurizio Vaudagna, eds., Democracy and the Welfare State. The Two Wests in the Age of Austerity, New York, Columbia University Press, 2018, 424 pages, $80 €$, ISBN: 978-0231180344

1 Edited by Alice Kessler-Harris and Maurizio Vaudagna, Democracy and the Welfare State. The Two Wests in the Age of Austerity is a comparative study of welfare regimes and democratic participation in Europe and the United States. The "Two Wests" paradigm has been fruitfully explored by the authors for more than a decade and this book is the latest publication, following Democracy and Social Rights in the Two Wests, issued in 2009. Against those who see the Welfare State as "an exclusively European affair, the "Two Wests" concept "acknowledges that the United States and Europe share a common history of social rights designed to enhance national loyalty and democratic participation among their citizens" but also recognizes crucial differences "between Europe and America and among European nation-states" (21). Drawing on the products of a workshop held in Paris in 2014, this book abandons the state-centered perspective adopted in 2009 to concentrate instead on the "effect of neoliberal ideas" and "free market fundamentalism" on state priorities. This leads some contributors to focus on institutions fostered by the state, such as prisons, the family or the workplace.

2 Alice Kessler Harris's introduction provides a good presentation of the theoretical perspective adopted and briefly presents the book's chapters. Maurizio Vaudagna's 
chapter then gives a very useful overview of the historiography on the Welfare State from 1975 to 1995, laying particular emphasis on the growing role of gender and feminism in the study of welfare. Taken together, these two chapters serve as an extended introduction to the book.

The first part, entitled "Democracy and the Welfare State in Europe and the United States" features Maurizio Ferrara's study of the relations between the European Union and national Welfare States followed by an interview of Ira Katznelson on "Democracy after the Welfare State," which insists on the potential for popular participation in America. Ferrara's chapter tries to reconcile the European Union and the Welfare State and calls for enlightened statesmanship from above in order to promote a new European-led welfarism. Such a call ignores the tensions within the European Union between the richest and the poorest members and sounds overly optimistic given the conflicts which have arisen since 2014 in Europe.

The second part deals with "Varieties of Retrenchment" and offers five areas in which this retrenchment took place. Christian Lammert's study of Welfare State development in Europe and the United States since the 1990s shows how the shift towards privatization has helped increase inequality and limited democratic participation. Gro Hageman's detailed exploration of social citizenship in Norway and Sweden explains how the two Nordic countries implemented their own versions of the Third Way without eliminating the core features of the universalist welfare state. However, she argues that because of an aging population, privatization and immigration, the social pact is now under threat. Beatrix Hoffman's analysis of social citizenship in the US Affordable Care Act shows how the abandonment of the public option in order to secure passage of the bill through the US Congress shortchanged the poorest Americans as it prevented the rise of a universal system of insurance which is vitally needed to help citizens mobilize for the defence of their rights. Based on ethnographic fieldwork, Sébastien Chauvin's excellent study of the urban "precariat" in Chicago shows how different categories of temporary workers exist in Chicago. While "casual temps" are employed in multiple factories for multiple agencies, "regular temps" work for multiple companies while remaining loyal to the same agencies and "permatemps" work for the same factory for years. While African-Americans tend to work as regular temps, undocumented Latino immigrants work as regular temps and even benefit from informal careers. The paternalistic relations created by this system limits opportunities for political participation. Finally, Mimi Abramowitz deals with the shift from the "Welfare State to the Carceral State," undercutting social reproduction and democratic participation.

5 The third part of the book studies "Gender, the Family and Social Provision." It focuses on the connection between social provision and the welfare state. The sociologist Chiara Saraceno compares different sets of policies relating to maternity and parental leave, childcare and pensions in European countries. Despite differences which have persisted in the last decades, a measure of convergence is emerging for the care of young children even though disparities persist as far as care for the elderly is concerned. Ann Shola Orloff compares gendered labor policies in Sweden and in the United States since the 1960 s in order to study how maternal employment has increasingly been promoted. In Sweden, the growth of maternal employment has led to more equality in wages and family arrangements, which in turn has tended to improve the political participation of women. Robert Self's analysis of breadwinner liberalism, a 
nonuniversal welfare system based on a male-breadwinner model of rights and citizenship, explains how it emerged and how it has been challenged in the last few decades by women and minorities.

6 The last section deals with possibilities of resistance to neoliberal attacks on welfare. Birte Siim shows how transnational European civil society can resist the rise of xenophobic nationalism in a context marked by the backlash against immigration. Marisa Chappell concentrates on the attempts by ACORN (the Association of Community Organizations for Reform Now), an organization of low-income Americans, to campaign for social and political rights for all in the United States in the past thirty years. She shows how this group's demands have been denounced by mainstream and conservative groups despite changing strategies to try and unite and mobilize the poor. Finally, an interview of Frances Fox Pivens deals with the possibilities of grassroots challenges to capitalism, which would require a widespread popular revolt in order to succeed.

7 The book's depth and breadth is impressive. Comparing the two traditions of welfare provision in Europe and the United States helps the reader understand how liberalism has challenged the welfare state in different ways. The book's focus on austerity and neoliberalism rather than individual countries is illuminating insofar as it enables some of the authors to concentrate on questions of gender, employment rights, and the carceral state, which transcend national boundaries. However, the decision not to look at individual nations in detail sometimes means that "austerity" and "neoliberalism" sound a bit abstract and far removed from the concrete realities on the ground. The book concentrates on the United States and on the Scandinavian countries but leaves out southern and Eastern Europe entirely. Given the violence of austerity policies implemented in Spain, Greece and Eastern Europe, the omission is regrettable. Of course the fact that many events have occurred between the 2014 seminar and the 2017 publication (Brexit, the Greek crisis, the Italian election, Trump's election etc.) partly accounts for the gap between the book's prudently optimistic tone and the new reality in Europe and in the United States. Overall, given its wide range, the quality of its prose and impeccable editing, its great bibliography and useful index, this collection of essays is indispensable reading for anyone interested in the evolution of the Welfare States on both sides of the Atlantic and its implication for the future of democracy.

INDEX

Subjects: Recensions

\section{AUTHORS}

\section{LUC BENOIT À LA GUILLAUME}

Université de Rouen-Normandie 